\title{
Thunderstorms and thunderstorm precipitations in southern Poland
}

\author{
Zuzanna Bielec-Bąkowska \\ Department of Climatology, Faculty of Earth Sciences, University of Silesia, Będzińska Str. 60, 41-200 Sosnowiec, Poland \\ E-mail address: zuzanna.bielec-bakowska@us.edu.pl
}

\begin{abstract}
This paper addresses spatial and temporal variability in the occurrence of thunderstorms and related precipitation in southern Poland between 1951 and 2010. The analysis was based on thunderstorm observations and daily precipitation totals (broken down into the few ranges) from 15 meteorological stations. It was found that precipitation accompanied an overwhelming majority of thunderstorms. The most frequent range of thunderstorm precipitation totals was $0.1-10.0 \mathrm{~mm}$ which accounted for $60 \%$ of all values while precipitation higher than $20.0 \mathrm{~mm}$ accounted only for ca. $8 \%$. During the study period, long-term change in the number of days with thunderstorm precipitation within a certain range displayed no clearcut trends. Exceptions included: 1) an increase in the number of days with thunderstorm precipitation in the lowest range of totals (0.1-10.0 mm) at Katowice, Tarnów, Rzeszów and Lesko and decrease at Mt. Kasprowy Wierch, 2) an increase in the range 10.1-20.0 $\mathrm{mm}$ at Zakopane and $20.1-30.0 \mathrm{~mm}$ at Opole, 3) a decrease of the top range (more than $30.0 \mathrm{~mm}$ ) at Mt. Śnieżka. It was found that the heaviest thunderstorm precipitation events, i.e. totalling more than $30 \mathrm{~mm}$, and those events that covered all or most of the study area, occurred at the time of air advection from the southern or eastern sectors and a passage of atmospheric fronts.
\end{abstract}

KEY WORDS: thunderstorm day, thunderstorm precipitation, long-term variability, Poland

\section{Introduction}

Evidence of climate change has been mounting for years now, including some symptoms that are open to individual observation, such as sudden weather change and extreme meteorological events. In Poland thunderstorms tend to be classified as such events, even if not always correctly (BIELECBĄKOWSKA, 2013). Certainly among the most dangerous events are thunderstorms accompanied by violent changes in other elements of the weather, such as strong gusts of wind, powerful atmospheric discharges and heavy precipitation. The magnitude of these changes may vary depending on the magnitude and dynamics of the phenomenon in question. Like with other extreme events thunderstorms leave in their wake a trail of adverse effects on the environment (e.g. broken trees, precipitation-triggered landslides or floods), on the economy (e.g. ruptured power lines, damaged buildings, interrupted radio transmission and irregularities in air traffic) (CHANGNON, 2001a; BODZAK, 2004; BIELEC-BĄKOWSKA \& MATUSZKO, 2006) and on human health (e.g. in the cardio-vascular, nervous, and respiratory systems, headache, rheumatic pains, burning eyes and bowel disorders; KOZŁOWSKA-SZCZĘSNA ET AL., 2004). These effects are particularly significant in densely populated and industrialised areas where any damage is multiplied in a domino effect. For this reason it is important to understand the nature of change in the occurrence of thunderstorms and their accompanying phenomena. Research of this kind has been popular in many regions of the world (ChANGNon, 1985; ChANGNon, S.A. \& CHANGNON D., 2001; DAI, 2001; ZHENG ET AL., 2010; WEI ET AL., 2011; KULESHOV, 2012; SAHA ET AL., 2014). Its results point to a wide regional variability in the change of thunderstorm frequency and question marks over the significance of trends (IPCC, 2013; BRooKs, 2013). In Poland and its neighbouring countries the directions of trends in these elements can also vary (BRÁZDIL ET AL., 1998; KUNZ ET AL., 2009; SiMEONOV ET AL., 2009; LOGINOV ET AL., 2010; BIELECBĄKOWSKA, 2013; ENNO ET AL., 2014). This variability may be caused by differences in the natural 
environment, especially in the types of atmospheric circulation over particular regions.

The objective of this study was to investigate the spatial and temporal variability of thunderstorms and accompanying precipitation in southern Poland. The study region was selected for its great economic significance, large population and highest incidence of thunderstorms. Additionally the study aimed to determine whether the change in frequency of thunderstorms also applied to the precipitation accompanying them. This decision was dictated by the selection of precipitation totals as one of the measures of thunderstorm intensity and by the fact that heavy precipitation played a significant role in this part of the country which is very prone to flooding. The study focused on the long-term change in discrete ranges of thunderstorm precipitation and on thunderstorm events recorded across the whole area during one day.

\section{Data and methodology}

The study was based on observation and measurement records taken between 1951 and 2010 at 14 synoptic stations of the Polish weather service network (IMGW) and at the Historic Station of the Jagiellonian University in Krakow known for one of the longest unbroken observation records in Poland (Fig. 1).

Certain assumptions needed to be adopted for the analysis of thunderstorm precipitation for a number of reasons, including: 1) the subjectivity and inaccuracies inherent in thunderstorm observations, 2) a considerable degree of spatial variability of thunderstorms and thunderstorm precipitation, and 3) the lack of availability of detailed data of their characteristics. For these reasons a decision was taken to base the analysis on the number of days with a thunderstorm and the daily precipitation totals. Unfortunately, some of the records had gaps, including: Racibórz: no data from 1969; Rzeszów: records start in 1952; Lesko: records start in 1955.

The two phenomena included in the analysis display a high degree of inherent spatial variability and susceptibility to local environmental influences. These effects are particularly visible in the occurrence and observation of thunderstorms (qualitative data) and the variability of precipitation in areas with diverse landform (such as in southern Poland). For this reason verification of the selected data series for homogeneity is not an easy task. It was accomplished in three steps, including: 1) analysis of station history (metadata), 2) a comparison of specific element data between those stations nearest to each other, and 3) a comparison of such data using the Standard Normalised Homogeneity Test (ALEXANDERSSON, 1986) with AnClim package (ŠTĚPÁNEK, 2010; http://www.climahom.eu/AnClim.html). Doubts about the number of days with a thunderstorm were verified against data on atmospheric discharge and using synoptic maps.

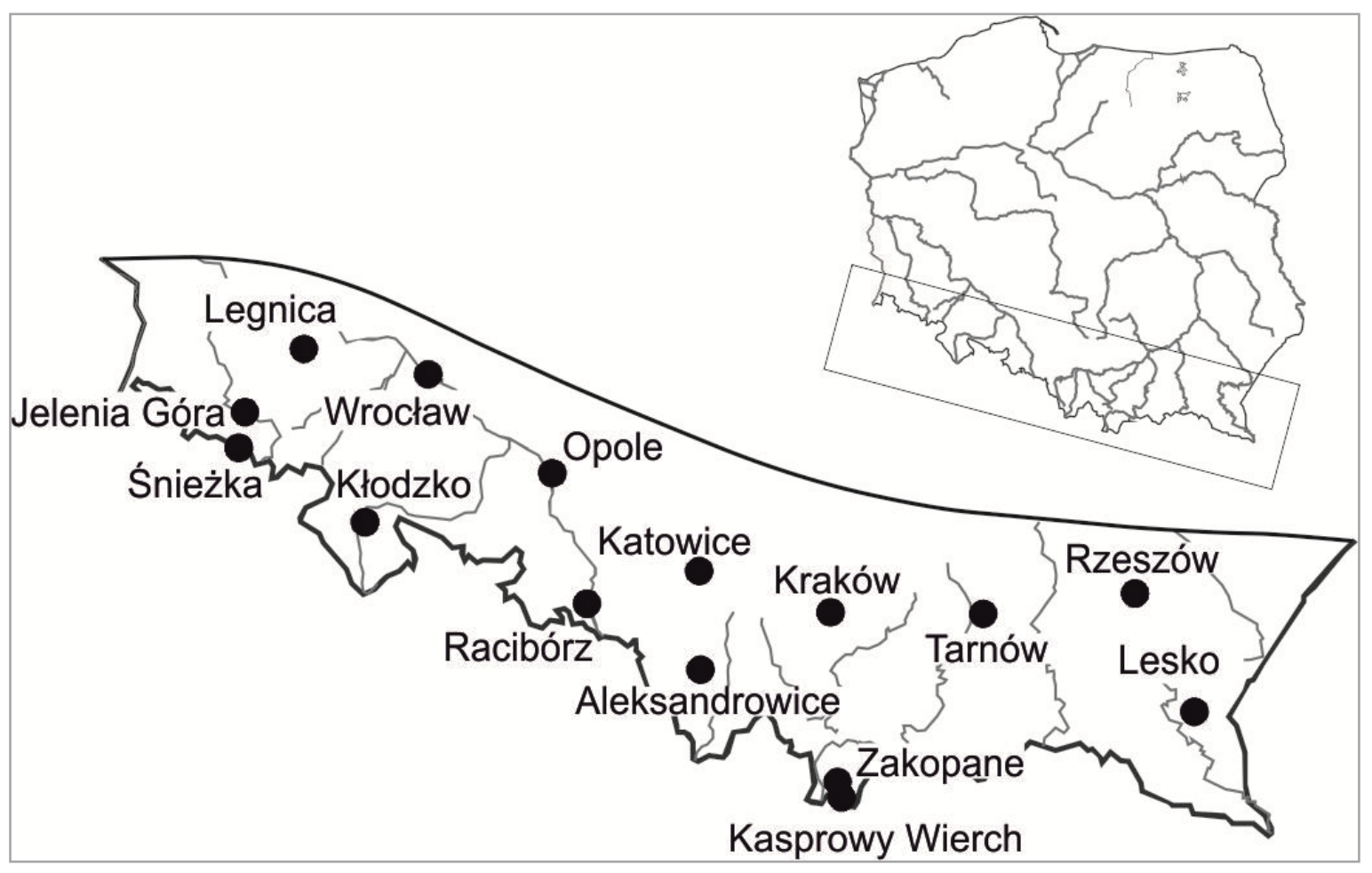

Fig. 1. Meteorological stations used in the study 
According to the instruction for meteorological stations in Poland (JANISZEWSKI, 1988), a thunderstorm is one or a few sudden discharges of atmospheric electricity, recorded as a short and strong sparkle (i.e. a lighting), accompanied by a crack or rumbling (i.e. a thunder) which occurs inside a Cumulonimbus cloud or between the cloud and the ground. The beginning of a thunderstorm is the moment of the first thunder occurrence noticed by an observer, and a thunderstorm is considered finished at the moment of the last thunder occurrence, provided there is no thunder noticed during next 15 minutes. However, in the paper a day with thunderstorm rather than thunderstorm occurrences became a basic index used during analysis. In this way the authors narrowed down the error margin involved in the observer's subjective decisions. Such errors, especially in pinpointing the thunderstorm's start, finish and location vis-à-vis the station, are mostly caused by the station's location, weather conditions influencing sound propagation, background noise and by observer skills (REAP \& ORVILLE, 1990; ChANGNon, 1993, 2001b; BIELEC \& KolendowiCZ, 2001).

For the purpose of the study a day with a thunderstorm is defined as a period between 00:01 and 24:00 UTC with at least one occurrence of a thunderstorm (whether near or far). The rare thunderstorm occurrences at turn of two days were counted on both days.

Detailed analysis of thunderstorm precipitation is immensely difficult to carry out and is only possible with detailed weather observations and hourly, or even better continuous, pluviogrammes. Due to the very limited availability of such data certain assumptions had to be adopted for the purpose and these were borrowed from earlier studies (BIELEC-BĄKOWSKA \& ŁUPIKASZA, 2009). The main assumption was that total thunderstorm precipitation was equal to the daily total on the day with the thunderstorm. Obviously, this is only an approximation that helps assess the order of magnitude of the thunderstorm precipitation, as it is not certain that all of the precipitation recorded on the day is directly related to the thunderstorm. On the other hand, even if due diligence is exercised by the observer it may not be possible to separate thunderstorm precipitation from that which comes from unrelated clouds that occur over the thunderstorm area. An example of this situation could be the passage of an atmospheric front complex of clouds with built-in Cumulonimbus clouds.

This study has broken down precipitation into the following ranges: 1) no or trace precipitation;
2) $0.1-10.0 \mathrm{~mm}$ - weak and moderate precipitation; 3) $10.1-20.0 \mathrm{~mm}$ - moderately strong precipitation; 4) 20.1-30.0 mm - strong precipitation: 5) more than $30.0 \mathrm{~mm}$ - very strong precipitation (OLECHNOWICZBOBROWSKA, 1970).

The precipitation totals used in this study were taken between 06:01 and 06:00 UTC. While this represents a certain shift from the adopted thunderstorm day, results of precipitation measurements and thunderstorm occurrence research indicate that precipitation totals on such days come nearly entirely from thunderstorm precipitation. Further details of this relationship are found in the previously mentioned study by BIELEC-BĄKOWSKA \& ŁUPIKASZA of 2009.

An important part of the study was the setting of multi-annual variability of the number of days with thunderstorm and accompanying precipitation. To achieve that goal, the variability of annual number of such days was studied, taking under consideration their division due to precipitation amount. For each station, the tendency of the changes was defined and the changes recorded at particular stations were compared to each other.

\section{Thunderstorms in southern Poland, their annual distribution and accompanying precipitation}

Southern Poland is characterised by the country's highest incidence of thunderstorms. This is a result of the orographic barrier effect and of an increased component of advection from the south, east and north sectors (BIELEC-BĄKOWSKA, 2002; Kolendowicz, 2005). The study found that at a majority of stations the annual average number of days with a thunderstorm was 3-4 days higher than the national average (23.6 days per year; BIELEC-BĄKOWSKA, 2002). The only exceptions were Jelenia Góra and Opole where it was close to the average, however in Zakopane, Lesko and at Mt. Kasprowy Wierch thunderstorm were recorded even more than during 30 days per year (Tab. 1).

Most of the thunderstorms were accompanied by small amounts of precipitation up to $10.0 \mathrm{~mm}$. Generally, there were between 15 and 18 days a year with a thunderstorm with this amount of rain (Tab. 2). There were many fewer thunderstorm days with 10.1-20.0 mm of precipitation. There accounted for an average of 3-5 days with only the stations in Zakopane and at Mt. Kasprowy Wierch recording 1-2 days more. Naturally, there were specific years, when these totals would be higher, but they topped 10 days at just four stations: 11 days at Zakopane in 2002 and 2003; 11 days at Mt. Śnieżka in 1975, 13 days at Mt. Kasprowy Wierch 
in 1959 and 14 days at Katowice in 1974. Days with thunderstorm precipitation greater than 20.0 or $30.0 \mathrm{~mm}$ are exceptionally rare; the range 20.1-30.0 mm occurred in 40 while totals greater than $30.0 \mathrm{~mm}$ occurred only in about 30 of the 60 years in the period.

Table 1. Annual number of days with thunderstorm in the period 1951-2010

\begin{tabular}{|l|c|c|c|}
\hline \multirow{2}{*}{\multicolumn{1}{|c|}{ Station }} & \multicolumn{3}{|c|}{ Annual number of days } \\
\cline { 2 - 4 } & the lowest & average & the highest \\
\hline Legnica & 15 & 27.3 & 41 \\
Wrocław & 15 & 25.2 & 43 \\
Jelenia Góra & 14 & 24.0 & 34 \\
Śnieżka & 16 & 25.2 & 39 \\
Kłodzko & 13 & 26.9 & 37 \\
Opole & 11 & 24.1 & 36 \\
Racibórz & 10 & 26.8 & 39 \\
Katowice & 18 & 28.1 & 41 \\
Kraków & 17 & 27.0 & 40 \\
Tarnów & 17 & 27.1 & 40 \\
Rzeszów & 18 & 27.8 & 41 \\
Aleksandrowice & 16 & 27.1 & 45 \\
Zakopane & 19 & 31.0 & 47 \\
Kasprowy Wierch & 19 & 32.6 & 54 \\
Lesko & 23 & 34.4 & 48 \\
\hline
\end{tabular}

The proportion of the number of days with a specific range of precipitation totals to the overall number of thunderstorm days is similar across all stations and is characteristic of this part of Poland. The proportion of thunderstorm days with trace or no precipitation is quite high at typically ca. $13 \%-20 \%$ of all thunderstorm days (Tab. 3 ). High mountain stations as well as stations at Aleksandrowice and Zakopane stand out here with a proportion of $8.2 \%-10.7 \%$. Overall, the frequency of thunderstorm precipitation occurrence followed a downward pattern on the scale of precipitation ranges: ca. $60 \%$ of days were accounted for by the range of $0.1-10.0 \mathrm{~mm}, \mathrm{ca} .15 \%$ by the range $10.1-$ $20.0 \mathrm{~mm}$, ca. $5 \%$ by the range $20.1-30.0 \mathrm{~mm}$ and ca. $3 \%$ by values of over $30.0 \mathrm{~mm}$ of rain. A closer look at the details allowed the identification of areas with patterns that differ from the overall trend. The most peculiar are three high-placed stations at Aleksandrowice, Zakopane and Mt. Kasprowy Wierch with a lower proportion of thunderstorm days with zero to $10.0 \mathrm{~mm}$ of precipitation and a higher proportion with strong or very strong precipitation. The other group of stations that stand out involve Katowice, Kraków, Tarnów, Rzeszów and Lesko, with proportions of the bottom two ranges of totals, i.e. $0.1-10.0 \mathrm{~mm}$ and $10.1-20.0 \mathrm{~mm}$, slightly higher than those recorded in the west of the area (Tab. 3, Fig. 2).

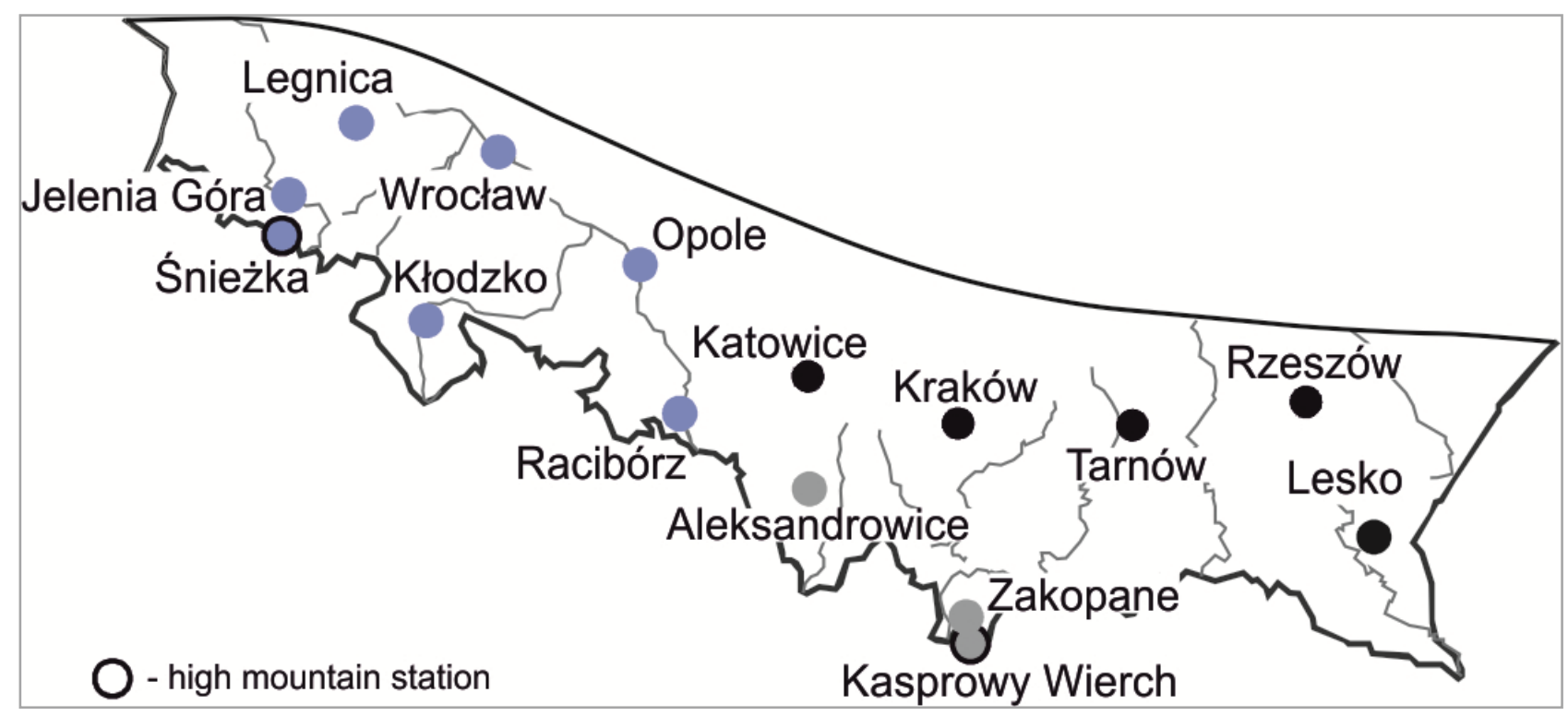

Fig. 2. The groups of stations distinguished by frequency of the occurrence of the thunderstorm days with different precipitation categories in the period 1951-2010 - explanation in the text

An annual pattern was the most characteristic feature of thunderstorm occurrence. Most thunderstorms occur in the warm season (April-September), when most of the stations record more than 90\% of their incidences (BIELEC-BAKOWSKA, 2002).
Whereas, the Maximum Thunderstorm Activity Season normally begins in mid-May and lasts until the second half of August, during which time more than two days with a thunderstorm are recorded (KolENDOWICZ, 2005). Indeed, all of the 
stations in the study recorded their thunderstorm precipitation maximums in each individual range in one of the summer months. However, it would be difficult to name a more specific rule determining the occurrence of the annual maximum, especially in the rare occurrences of the highest totals. Often a given month would claim the maximum due to a difference of just one day and no single month concentrated all of a given station's range maximums. The only two general patterns identifiable include: 1) the almost invariable peaking of the $0.1-10.0 \mathrm{~mm}$ precipitation range in June and the $30.0 \mathrm{~mm}$-plus typically in July (Tab. 4), and 2) while thunderstorms after October were sporadic in all precipitation ranges, the onset of the thunderstorm season differed between them. Thunderstorm days without precipitation and those with more than $10.0 \mathrm{~mm}$ of rain began to pick up in frequency around mid-April, while the range $0.1-10.0 \mathrm{~mm}$ could easily occur as early as March (Fig. 3). Katowice (not shown) and Kraków provide an exception here with a "sizable" proportion of days with thunderstorm precipitation of this amount also noted in winter (Fig. 3).

Table 2. Annual number of days with thunderstorm and precipitation in the period 1951-2010

\begin{tabular}{|c|c|c|c|c|c|c|}
\hline \multirow{2}{*}{$\begin{array}{c}\text { Precipitation } \\
{[\mathrm{mm}]}\end{array}$} & \multicolumn{6}{|c|}{ Number of days with thunderstorm } \\
\hline & average & the highest & average & the highest & average & the highest \\
\hline & \multicolumn{2}{|c|}{ Legnica } & \multicolumn{2}{|c|}{ Wrocław } & \multicolumn{2}{|c|}{ Jelenia Góra } \\
\hline no or trace & 5.4 & 12 & 4.4 & 9 & 3.8 & 12 \\
\hline $0.1-10.0$ & 17.0 & 26 & 15.6 & 31 & 14.8 & 22 \\
\hline $10.1-20.0$ & 3.1 & 8 & 3.5 & 9 & 3.5 & 8 \\
\hline $20.1-30.0$ & 1.1 & 4 & 1.0 & 3 & 1.2 & 4 \\
\hline \multirow[t]{2}{*}{$\geq 30.1$} & 0.8 & 3 & 0.8 & 4 & 0.8 & 3 \\
\hline & \multicolumn{2}{|c|}{ Śnieżka } & \multicolumn{2}{|c|}{ Kłodzko } & \multicolumn{2}{|c|}{ Opole } \\
\hline no or trace & 2.6 & 7 & 5.1 & 13 & 3.9 & 10 \\
\hline $0.1-10.0$ & 15.6 & 25 & 15.9 & 24 & 14.9 & 24 \\
\hline $10.1-20.0$ & 4.2 & 11 & 3.5 & 10 & 3.6 & 10 \\
\hline $20.1-30.0$ & 1.2 & 4 & 1.5 & 4 & 1.1 & 4 \\
\hline \multirow[t]{2}{*}{$\geq 30.1$} & 1.6 & 5 & 1.0 & 4 & 0.7 & 4 \\
\hline & \multicolumn{2}{|c|}{ Racibórz } & \multicolumn{2}{|c|}{ Katowice } & \multicolumn{2}{|c|}{ Kraków } \\
\hline no or trace & 4.2 & 12 & 3.6 & 16 & 3.6 & 8 \\
\hline $0.1-10.0$ & 16.5 & 25 & 17.8 & 29 & 16.8 & 28 \\
\hline $10.1-20.0$ & 3.8 & 9 & 4.5 & 14 & 4.5 & 9 \\
\hline $20.1-30.0$ & 1.4 & 5 & 1.3 & 4 & 1.2 & 5 \\
\hline \multirow[t]{2}{*}{$\geq 30.1$} & 0.9 & 4 & 1.0 & 4 & 0.9 & 3 \\
\hline & \multicolumn{2}{|c|}{ Tarnów } & \multicolumn{2}{|c|}{ Rzeszów } & \multicolumn{2}{|c|}{ Aleksandrowice } \\
\hline no or trace & 3.7 & 11 & 4.6 & 10 & 2.6 & 6 \\
\hline $0.1-10.0$ & 17.1 & 29 & 17.1 & 26 & 15.6 & 29 \\
\hline $10.1-20.0$ & 4.1 & 8 & 4.2 & 8 & 5.3 & 10 \\
\hline $20.1-30.0$ & 1.4 & 4 & 1.1 & 4 & 2.1 & 8 \\
\hline \multirow[t]{2}{*}{$\geq 30.1$} & 0.8 & 4 & 0.8 & 4 & 1.5 & 4 \\
\hline & \multicolumn{2}{|c|}{ Zakopane } & \multicolumn{2}{|c|}{ Kasprowy Wierch } & \multicolumn{2}{|c|}{ Lesko } \\
\hline no or trace & 3.3 & 7 & 2.7 & 8 & 4.9 & 12 \\
\hline $0.1-10.0$ & 17.7 & 28 & 18.3 & 36 & 21.5 & 33 \\
\hline $10.1-20.0$ & 5.9 & 11 & 6.9 & 13 & 5.3 & 11 \\
\hline $20.1-30.0$ & 2.2 & 5 & 2.6 & 8 & 1.6 & 5 \\
\hline$\geq 30.1$ & 1.9 & 5 & 2.1 & 5 & 1.1 & 5 \\
\hline
\end{tabular}


Table. 3. Frequency [\%] of certain daily sums of precipitation occurrence on the days with thunderstorm in the period 1951-2010

\begin{tabular}{|l|c|c|c|c|c|c|}
\hline \multirow{2}{*}{\multicolumn{1}{|c|}{ Station }} & \multicolumn{5}{|c|}{ Frequency [\%] } \\
\cline { 2 - 7 } & no or trace & $0.1-10.0 \mathrm{~mm}$ & $10.1-20.0 \mathrm{~mm}$ & $20.1-30.0 \mathrm{~mm}$ & $\geq 30.1 \mathrm{~mm}$ & sum \\
\hline Legnica & 19.7 & 62.3 & 11.3 & 3.9 & 2.7 & 100.0 \\
Wrocław & 17.3 & 61.8 & 14.0 & 3.8 & 3.1 & 100.0 \\
Jelenia Góra & 15.9 & 61.5 & 14.6 & 4.8 & 3.3 & 100.0 \\
Śnieżka & 10.5 & 62.0 & 16.7 & 4.7 & 6.2 & 100.0 \\
Kłodzko & 18.9 & 58.8 & 13.1 & 5.5 & 3.7 & 100.0 \\
Opole & 16.0 & 61.6 & 15.1 & 4.6 & 2.8 & 100.0 \\
Racibórz & 15.8 & 61.7 & 14.2 & 5.1 & 3.2 & 100.0 \\
Katowice & 12.7 & 63.3 & 16.1 & 4.6 & 3.4 & 100.0 \\
Kraków & 13.3 & 62.2 & 16.7 & 4.6 & 3.2 & 100.0 \\
Tarnów & 13.5 & 63.1 & 15.3 & 5.2 & 3.0 & 100.0 \\
Rzeszów & 16.4 & 61.5 & 15.0 & 4.0 & 3.1 & 100.0 \\
Aleksandrowice & 9.6 & 57.7 & 19.5 & 7.7 & 5.5 & 100.0 \\
Zakopane & 10.7 & 57.1 & 19.1 & 7.1 & 6.1 & 100.0 \\
Kasprowy & 8.2 & 56.2 & 21.1 & 8.0 & 6.5 & 100.0 \\
Wierch & 14.3 & 62.3 & 15.4 & 4.9 & 3.1 & 100.0 \\
Lesko & & &
\end{tabular}

Table 4. Annual maximum of certain daily sums of precipitation occurrence on the days with thunderstorm in the period 1951-2010

\begin{tabular}{|l|c|c|c|c|c|}
\hline \multirow{2}{*}{ Station } & \multicolumn{5}{|c|}{ Annual maximum } \\
\cline { 2 - 6 } & no or trace & $0.1-10.0 \mathrm{~mm}$ & $\begin{array}{c}10.1-20.0 \\
\mathrm{~mm}\end{array}$ & $\begin{array}{c}20.1-30.0 \\
\mathrm{~mm}\end{array}$ & $\geq 30.1 \mathrm{~mm}$ \\
\hline Legnica & VII & VI & VII & VII & VII \\
Wrocław & VIII & VI & VII & VII & VII \\
Jelenia Góra & VIII & VI & VI & VII & VII \\
Śnieżka & VIII & VI & VI & VI & VII \\
Kłodzko & VI & VI & VII & VI-VII & VIII \\
Opole & VII & VI & VII & VII & VII \\
Racibórz & VI & VI & VII & VII & VII \\
Katowice & VII & VI & VII & VII & VII \\
Kraków & VI & VII & VII & VI & VII \\
Tarnów & VII & VI & VII & VIII & VI-VII \\
Rzeszów & VII & VII & VII & VI & VII \\
Aleksandrowice & VII & VI & VI & VI & VI \\
Zakopane & VIII & VI & VII & VII & VII \\
Kasprowy & VIII & VI & VI & VII & VII \\
Wierch & VI & VI & VII & VII & VII \\
Lesko & & & &
\end{tabular}

\section{Long-term variability of thunderstorm precipitation}

The numbers of days with a thunderstorm varied from year to year over the study period (Fig. 4). The long-term variability indices ranged from $17.0 \%$ at Rzeszów to $21.8 \%$ at Aleksandrowice and at Mt. Kasprowy Wierch, while the long-term amplitude ranged from 20 days at Jelenia Góra to 29 at Racibórz and Aleksandrowice and to 35 days at Mt. Kasprowy Wierch. This change in the number of thunderstorm days and accompanying precipitation varied from station to station. The greatest similarities are found in the overall 

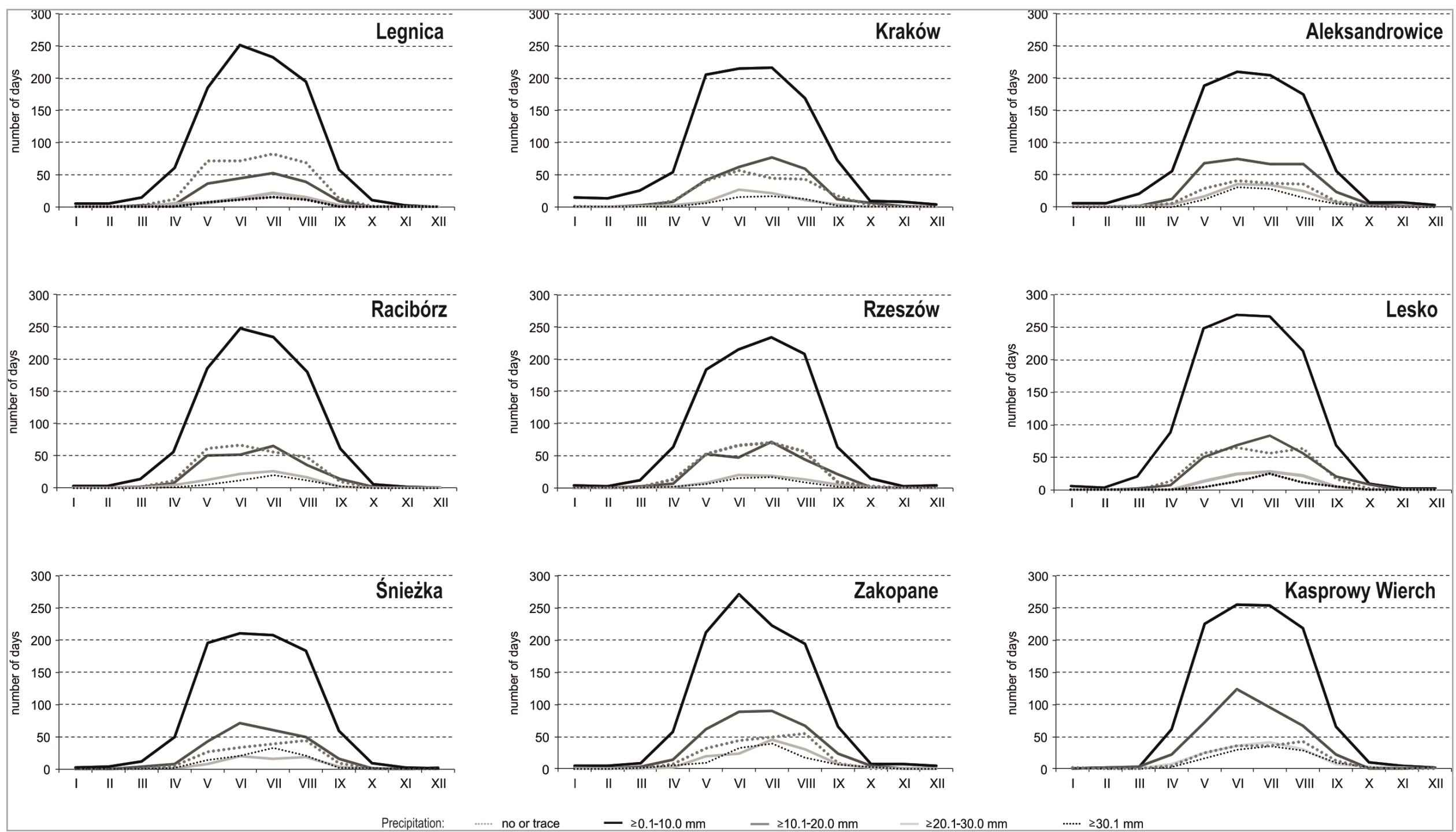

Fig. 3. Number of thunderstorm days with different precipitation categories in the period 1951-2010 - annual course 

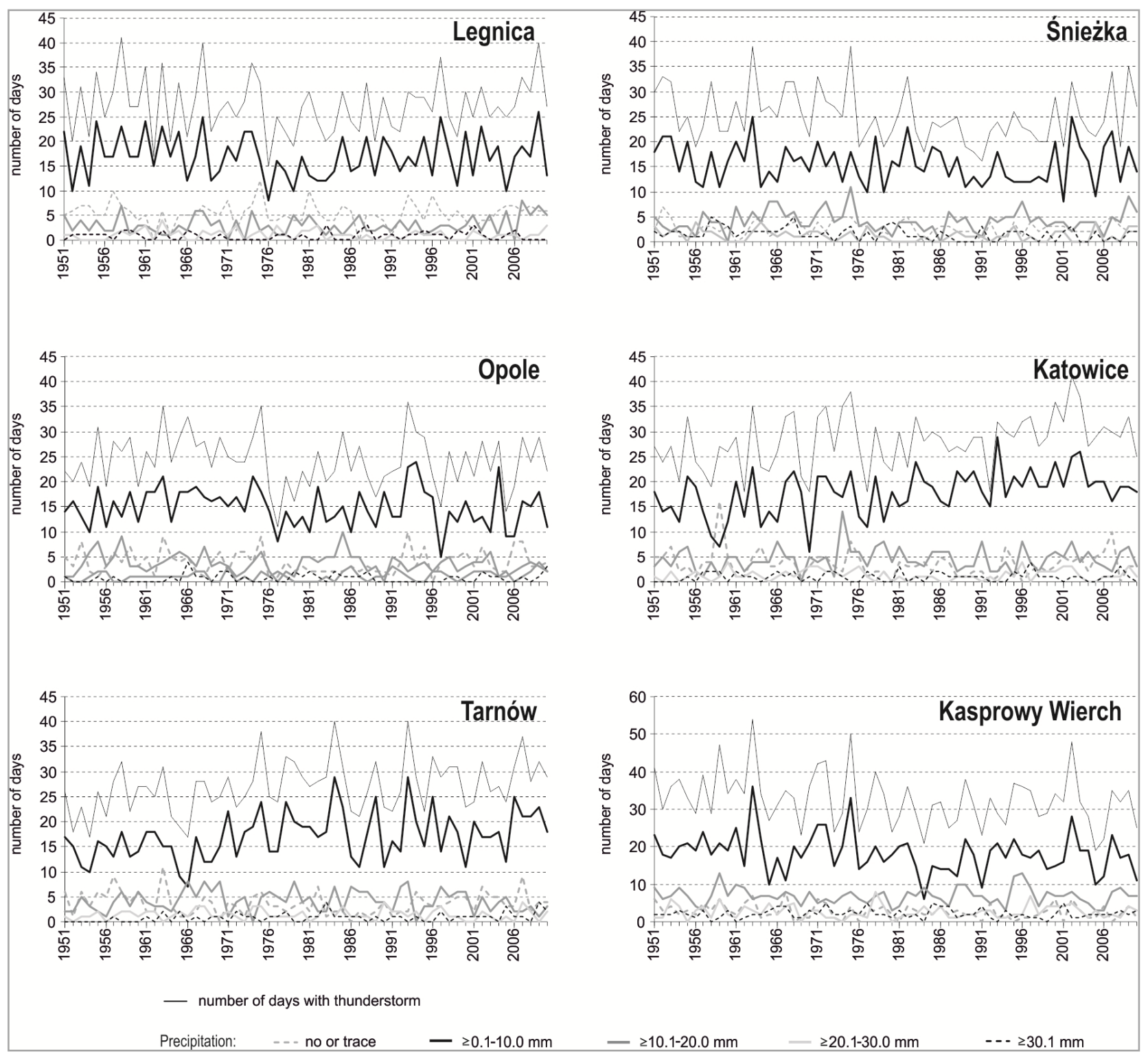

Fig. 4. Number of thunderstorm days with different precipitation categories in the period 1951-2010 - long term-variability

number of days with a thunderstorm and correlation coefficients (statistically significant at $\mathrm{p}<0.05$ ) were generally proportional to the distance between stations, as they ranged from ca. $0.51-0.68$ for neighbouring stations to ca. $0.25-0.40$ for stations located far apart. The stations that stood out the most were Lesko, Tarnów and Rzeszów, which did not correlate at all with stations located to the west of Katowice, while Rzeszów additionally did not correlate with thunderstorms recorded at Aleksandrowice, Zakopane and Mt. Kasprowy Wierch. Among other stations no correlation was found between Racibórz and Jelenia Góra, Mt. Śnieżka, Tarnów and Rzeszów, and between Katowice and Kraków and Opole. Similar, if weaker, patterns were observed in the precipitation range of $0.1-10.0 \mathrm{~mm}$. In all other ranges weak correlations were only identified between those stations located nearest to each other, which is explained primarily by the small sample of strong thunderstorm precipitation and its often local nature.

The study found that in contrast to a generally held belief that neither the number of days with a thunderstorm, nor the associated precipitation totals were increasing throughout the area and that the strength of any change found there depended on the station. In general an upward trend in the frequency of thunderstorm occurrence dominated and it was stronger in the east of the area (Fig. 5). However, it was statistically significant at just four stations: Katowice, Tarnów, Rzeszów and Lesko (respectively by 1.09, 1.07, 0.92 and 1.67 days per 10 years; Tab. 5).

There were also stations with a downward trend in the number of days with a thunderstorm: it was weak at Legnica, Opole and Mt. Śnieżka and statistically significant at Mt. Kasprowy Wierch ( -1.17 days per 10 years). Similar trends 
were found in the thunderstorm precipitation totals within the range $0.1-10.0 \mathrm{~mm}$, which normally accounts for more than $60 \%$ of all days with a thunderstorm. No clear trends were observed in any of the remaining precipitation ranges. However, the small size of the sample meant that only a very strong and consistent growth or fall in the number of days with thunderstorm precipitation of a certain total would make the result statistically significant. Exceptions here included Zakopane with an increase of thunderstorm precipitation in the range $10.1-20.0 \mathrm{~mm}$, Opole with an increase in the range $20.1-30.0 \mathrm{~mm}$ and Mt. Śnieżka with a decrease in the top precipitation range (Tab. 5). In the first two cases this is explained by an increase in the numbers of days with the totals in question in the second half of the study period, and increasingly in the final decade, while in the last case not only did the frequency of the specific precipitation total occurrence decrease, but there was an increasing number of years without any such day recorded.

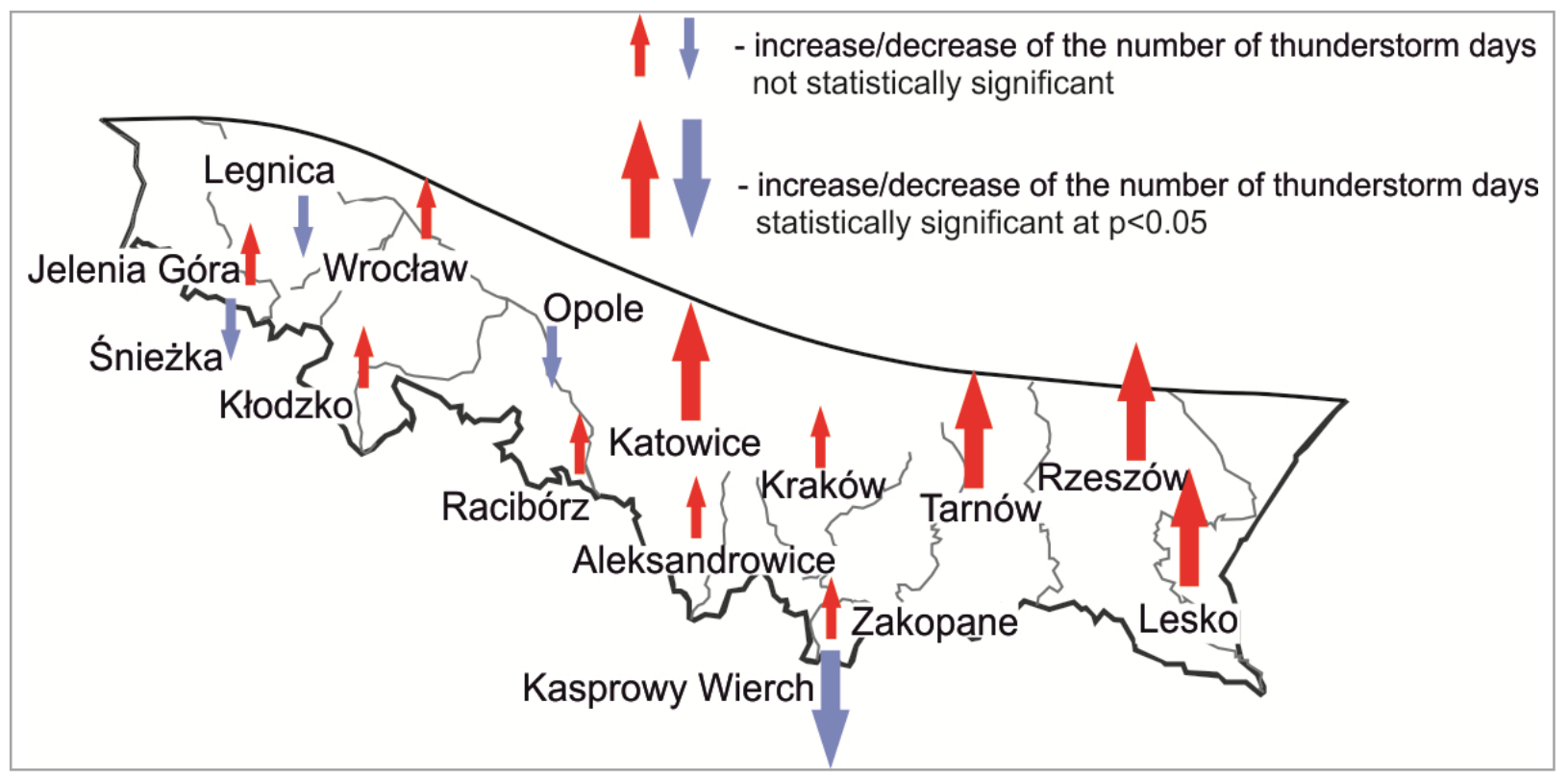

Fig. 5. Tendency of the annual number of the thunderstorm days occurrence in the period 1951-2010

Table 5. Tendency [days/10 years] of the thunderstorm days and certain daily sums of precipitation occurrence on the days with thunderstorm in the period 1951-2010

\begin{tabular}{|l|c|c|c|c|c|c|}
\hline \multirow{2}{*}{ Station } & \multicolumn{7}{|c|}{ Tendency [days/10 years] } \\
\cline { 2 - 7 } & no or trace & $0.1-10.0 \mathrm{~mm}$ & $\begin{array}{c}10.1-20.0 \\
\mathrm{~mm}\end{array}$ & $\begin{array}{c}20.1-30.0 \\
\mathrm{~mm}\end{array}$ & $\geq 30.1 \mathrm{~mm}$ & $\begin{array}{c}\text { days with } \\
\text { thunderstorm }\end{array}$ \\
\hline Legnica & -0.03 & -0.13 & 0.16 & -0.04 & 0.02 & -0.01 \\
Wrocław & 0.06 & 0.58 & -0.11 & 0.02 & 0.01 & 0.56 \\
Jelenia Góra & 0.28 & -0.13 & 0.00 & 0.05 & 0.45 & 0.26 \\
Śnieżka & -0.07 & -0.29 & 0.04 & -0.11 & $-0.23^{*}$ & -0.66 \\
Kłodzko & 0.05 & 0.13 & 0.11 & -0.15 & 0.03 & 0.17 \\
Opole & -0.01 & -0.29 & -0.19 & $0.15^{*}$ & 0.04 & -0.31 \\
Racibórz & 0.17 & 0.43 & 0.10 & -0.03 & 0.03 & 0.70 \\
Katowice & -0.23 & $1.17^{*}$ & 0.09 & 0.01 & 0.03 & $1.09^{*}$ \\
Kraków & -0.19 & 0.34 & 0.24 & -0.07 & -0.02 & 0.30 \\
Tarnów & -0.10 & $1.03^{*}$ & -0.05 & 0.01 & 0.18 & $1.07^{*}$ \\
Rzeszów & -0.02 & $0.64^{*}$ & 0.17 & 0.02 & 0.11 & $0.92^{*}$ \\
Aleksandrowice & -0.08 & 0.51 & 0.19 & 0.01 & 0.06 & 0.69 \\
Zakopane & 0.13 & 0.12 & $0.40^{*}$ & 0.03 & -0.03 & 0.66 \\
Kasprowy & -0.30 & $-0.80^{*}$ & -0.06 & 0.00 & -0.01 & $-1.17^{*}$ \\
Wierch & 0.04 & $1.06^{*}$ & 0.28 & 0.19 & 0.11 & $1.67^{*}$ \\
Lesko & & &
\end{tabular}

$1.25^{*}$ - value statistically significant at $\mathrm{p}<0.05$ 


\section{Exceptional thunderstorms and accompanying precipitation}

The present section shows the occurrence of thunderstorm days with the highest precipitation sums and the occurrence of days when thunderstorms were noted at all stations or at prevailing number of stations. As shown on Figure 6, the highest precipitation totals ranged from $65.0 \mathrm{~mm}$ at Rzeszów to $166.1 \mathrm{~mm}$ at Mt. Kasprowy Wierch (Fig. 6). At six stations the amount of precipitation exceeded $100.0 \mathrm{~mm}$ and these were either mountain stations or ones located within the strong influence of the Carpathian or Sudeten
Mountains. Also interesting is that at six stations the highest totals were recorded in the last decade of the period, of which five were located in the west of the area known to be the most exposed to dynamic wet atmospheric fronts. These cases of heavy precipitation occurred mostly in July, but other summer months were also represented. Heavy precipitation cases outside the summer months were recorded in April at Katowice, in May at Lesko and in September at Kraków. All of these totals were linked to the passage of atmospheric fronts and either an eastern or southern air advection (BIELEC-BĄKOWSKA \& ŁUPIKASZA, 2009).

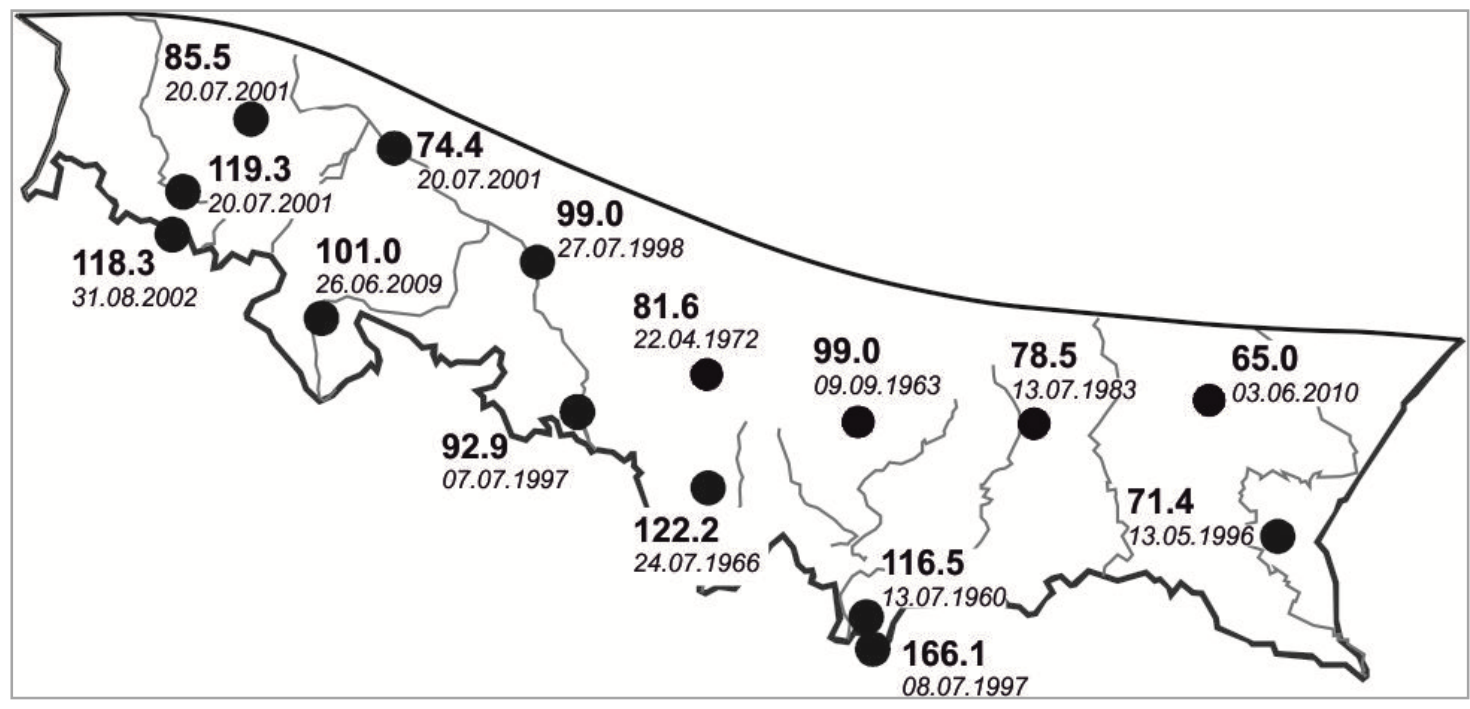

Fig. 6. The highest precipitation [mm] on the days with thunderstorm in the period 1951-2010

No less interesting are days, when all or a majority of stations recorded a thunderstorm. They were rather infrequent with 182 days with thunderstorms recorded at 10 stations (on average 3 per year) and just 28 days at all 15 stations (one in two years) (Fig. 7). There were only four years without a day with a thunderstorm at 10-11 stations (Fig. 7e-f), but 10-17 years without a day with a thunderstorm at $12-14$ stations (Fig. 7 b-d). There were only 21 years, when a thunderstorm was recorded at all 15 stations and never were there more than two such days in a year (Fig. 7a). Looking at the long-term variability of the frequency of thunderstorms at specific numbers of stations a perceptible change is only observed for thunderstorms recorded at 10 or more of the stations on a single day. The rate of increase was 1 day per 10 years. When looking at discrete numbers of stations and situations when a thunderstorm was observed on a single day, a small but statistically significant upturn of $0.2-$ 0.4 days per 10 years was recorded only in those cases in which a thunderstorm was observed at 12,14 and 15 stations.

On each of the 28 days when a thunderstorm was recorded at all stations there was at least one station with more than $10.0 \mathrm{~mm}$ of precipitation and 16 days when at least one station recorded more than $20.0 \mathrm{~mm}$. On two occasions, that latter range of strong precipitation was recorded at 5 stations (17 July 1965 and 20 July 2001), once at 8 stations (08 July 1996), once at 9 stations (12 August 1986) and at 12 stations (07 July 1997). The last of these examples was particularly characteristic with just three stations recording slightly lower totals (Tarnów, Rzeszów and Lesko) while Racibórz received its highest total of the entire study period $(92.9 \mathrm{~mm})$. This precipitation came from a low-pressure area slowly moving across Poland with a system of fronts that produced amounts of rain sufficient to trigger the first wave of a flood which engulfed the upper and middle sections of the Odra river basin in July 1997, as well as much of the Vistula river basin (DUBICKI ET AL., 1999; GRELA ET AL., 1999). 

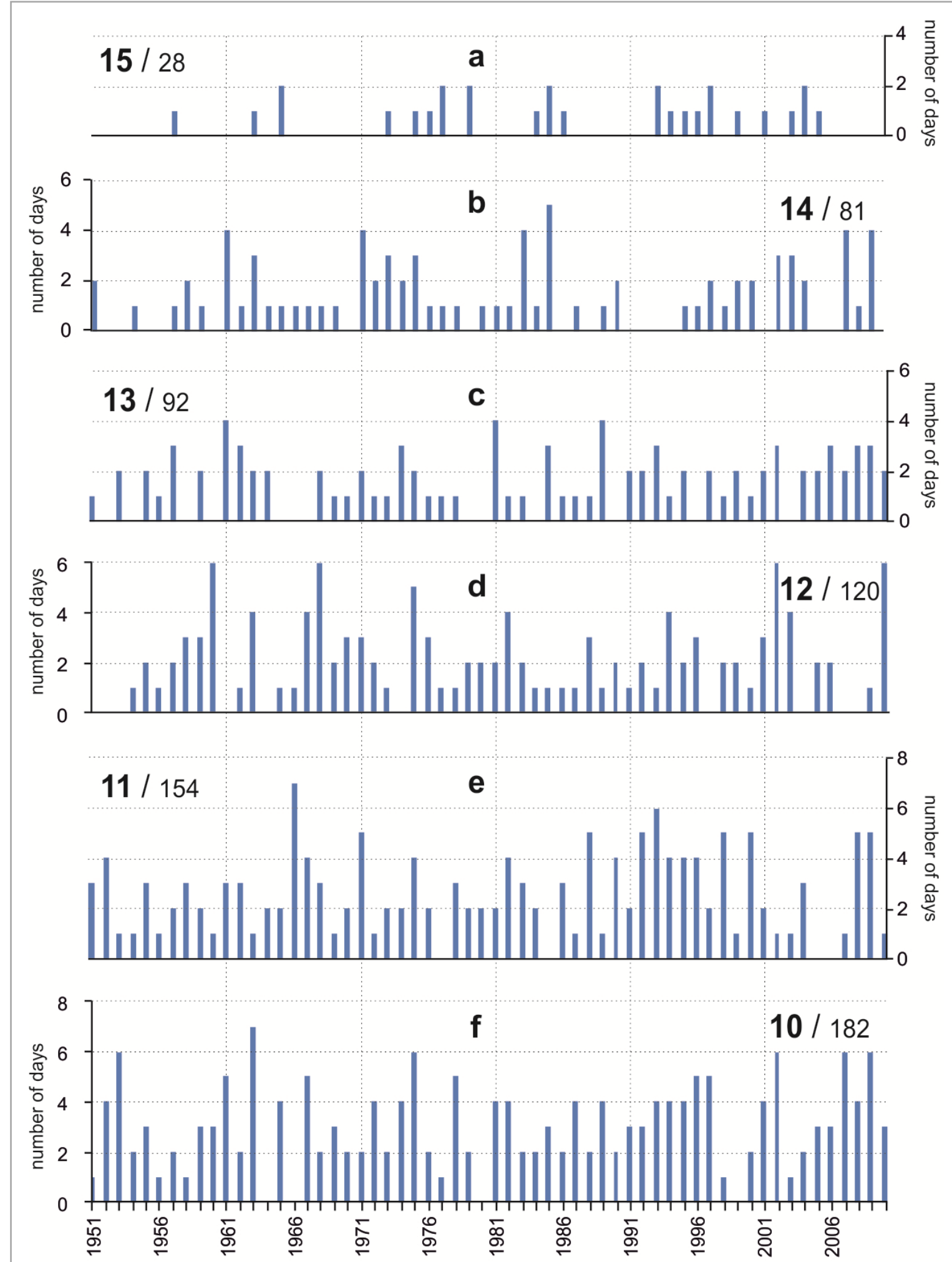

15 / 28 - number of stations with thunderstorm noted / number of thunderstorm days in the period 1951-2010

Fig. 7. Annual number of the days with thunderstorm recorded at certain number of stations in period 1951-2010

On 12 August 1986 and on 8 July 1996, the two days with multiple stations recording a thunderstorm were linked to warm fronts passing over the area while air was coming from the southern sector (WRONA, 2008; USTRNUL \& CZEKIERDA, 2009). In the former case thunderstorms were recorded at nearly all Polish stations located to the south of a line connecting the towns of Siedlce and Legnica (BIELEC-BĄKOWSKA \& ŁUPIKASZA, 2009) and five station of the study area recorded more than $40.0 \mathrm{~mm}$ of precipitation, including $65.0 \mathrm{~mm}$ at Mt. Śnieżka and $73.6 \mathrm{~mm}$ at Kłodzko. In the second 
of the cases, in 1996, the totals were even higher with $86.6 \mathrm{~mm}$ at Jelenia Góra and $75.1 \mathrm{~mm}$ at Legnica, both in the westernmost part of the area. That was also one of the days when heavy thunderstorm precipitation was recorded nearly across the whole of Poland (BIELEC-BĄKOWSKA \& ŁUPIKASZA, 2009). The most exceptional, however, was 20 July 2001 when an atmospheric front moving slowly across the country was accompanied by very heavy precipitation, especially in the west of Poland. The wavy cold front split the country along a line running from the Bay of Gdańsk to Opole and on to Moravia. To the east of that line warm tropical air was pouring in, while to the west of it the incoming polar maritime air was cooler and more humid. During the day a shallow cyclone area developed over Lower Silesia. A warm front linked to it developed conditions favourable to the formation of heavy precipitation with builtin storm clouds, while the rising terrain forced the air dynamically upwards triggering precipitation (WRONA, 2003). The result was that three stations (85.5 $\mathrm{mm}$ at Legnica, $74.4 \mathrm{~mm}$ at Wrocław and $119.3 \mathrm{~mm}$ at Jelenia Góra) recorded their period maximums, while two others also topped $30.0 \mathrm{~mm}$ (84.0 mm in Kłodzko and $52.6 \mathrm{~mm} \mathrm{Mt.} \mathrm{Śnieżka).}$ Four stations (Racibórz, Katowice, Tarnów and Mt. Kasprowy Wierch) recorded between $10.0 \mathrm{~mm}$ and $20.0 \mathrm{~mm}$ and the remaining ones received between $1.0 \mathrm{~mm}$ and $10.0 \mathrm{~mm}$. As a result, Poland experienced a flood which had a spatially greater extent than that of 1997 which latter was by far the most destructive.

\section{Discussion and conclusions}

The results presented in previous sections largely corroborate earlier research on the general characteristics of thunderstorm occurrence and accompanying precipitation in Poland. However, the narrower spatial focus and the extended timeframe allowed the identification of certain changes, which are not normally discernible when the number of stations is much greater. First and foremost the study found a clear change in the average number of days with a thunderstorm. Nearly all of the stations included in the study recorded a slight increase of that index which can be seen in the comparison of the data of 1949-1998 and 1949-2006. This increase is even more visible when the study period (1951-2010) is compared to observations from 1885-2008. Here the increase in the average annual number of days with a thunderstorm grows from a fraction of a day to ca. 1-2 days and the further westward a station is located the greater it is. Indeed, at Legnica the values increased from 23.6 days in 1885-2008 to 27.3 days in 1951-2010 (BIELEC-BĄKOWSKA, 2002, 2013).

Tendency of long-term variability of number of days with thunderstorm are weak and mostly not statistically significant. However, evidence of change typical of the entire country can be detected. These include a positive balance in the change of the number of days with a thunderstorm to the south of a line connecting the town of Suwałki and Mt. Śnieżka (up to more than 1 day per 10 years at Katowice, Tarnów, Rzeszów and Lesko) and a negative balance to the north of that line (at Legnica and at Mt. Śnieżka; BIELEC-BĄKOWSKA, 2013). One exception is a statistically significant decrease in the number of days with a thunderstorm at Mt. Kasprowy Wierch of -1.17 days per 10 years. When compared to regions neighbouring Poland the trends identified here fit in well with a long-term regionalisation of thunderstorm variability in Central Europe. This is confirmed by downward trends of change in the number of days with a thunderstorm in the Baltic countries (ENNO ET AL., 2014), a weak increase in western Belarus (LoGINOV ET AL., 2010), no change or a mild decline in Germany (KUNZ ET AL., 2009) and a decrease in both the number of days with a thunderstorm and hailstorm totals in Moravia (BRÁZDIL ET AL., 1998; CHROMÁ ET AL., 2005).

The other characteristic investigated here was the precipitation total. The particular internal regionalisation within southern Poland that was identified fits in well with general nationwide trends, i.e. most of the thunderstorms were accompanied by precipitation which was not normally greater than $10.0 \mathrm{~mm}$, which range accounts on average for ca. $60 \%$ of all days with a thunderstorm, and thunderstorm precipitation greater than $20.0 \mathrm{~mm}$ or $30.0 \mathrm{~mm}$ occurs on average on 3-8 days per year. These latter two ranges were growing in frequency at Aleksandrowice, Zakopane and Mt. Kasprowy Wierch, while stations with the greatest increases in the number of days with a thunderstorm (Katowice, Tarnów, Rzeszów and Lesko), as well as Kraków, recorded an increase frequency of thunderstorm precipitation in the ranges $0.1-10.0 \mathrm{~mm}$ and 10.1-20.0 mm. Like elsewhere in Poland longterm change in the number of days with thunderstorm precipitation within a certain range displayed no clear-cut trends. The one exception was the most frequent of the precipitation ranges, i.e. $0.1-10.0 \mathrm{~mm}$, which was recorded with a clearly increasing frequency at certain stations in the last years of the study period. This pattern and the occurrence of strong 
thunderstorm precipitation more frequently than once per year sets the region apart, especially its south-eastern part, from the rest of Poland (BIELEC-BĄKOWSKA \& ŁUPIKASZA, 2009). Another exception is a decrease in the highest totals at Mt. Śnieżka and an increase in the range 10.1$20.0 \mathrm{~mm}$ at Zakopane and in the range 20.1$30.0 \mathrm{~mm}$ at Opole. These exceptions may be few, but should not be disregarded because strong and very strong thunderstorm precipitation accounts for a high proportion of days with high totals in any given place (BIELEC-BĄKOWSKA \& ŁUPIKASZA, 2009; TWARDOSZ, 2010). These precipitation are most frequent in summer, are linked with atmospheric fronts and on the day tend to cover large areas (BIELEC-BĄKOWSKA \& ŁUPIKASZA, 2009). The strongest thunderstorms in the region develop on dynamic fronts linked with synoptic situations with air advection from the east, south or northwest sector (BRÁZDIL ET AL., 1998; BIELEC-BĄKOWSKA \& ŁUPIKASZA, 2009; KUNZ ET AL., 2009; LOGINOV ET AL., 2010; KoLENDOWICZ, 2005). These types of synoptic situations combined with the mountain barrier effect present in the region often result in the triggering or augmenting of floods. Therefore this study should be followed by an analysis of longterm change in atmospheric circulation and atmosphere stability in connection with the occurrence of thunderstorms and strong precipitation. This research should also look into the annual variability of both phenomena, especially in winter. These aspects are the more important, as knowledge of the direction of change in the occurrence of thunderstorms and their accompanying precipitation could help mitigate associated damage in the future in the most industrialised and populous area of Poland.

This study was supported by a grant from the Ministry of Science and Higher Education - National Science Center (N306 0479 39).

\section{References}

Alexandersson H. 1986. A homogeneity test applied to precipitation data. J. Climatol., 6: 661-675.

Bielec Z., Kolendowicz L. 2001. Problems connected with the observation and climatological elaborations of thunderstorms. Ann. UMCS Sect. B, 55/56, 7: 59-65.

Bielec-Bąkowska Z. 2002. Zróżnicowanie przestrzenne i zmienność wieloletnia występowania burz w Polsce (1949-1998). Wyd. Uniw. Śląskiego, Katowice.

Bielec-Bąkowska Z. 2013. Burze i grady w Polsce. Pr. Geogr. IGiGP UJ, 132: 99-132.

Bielec-Bąkowska Z., Łupikasza E. 2009. Long-term precipitation variability on thunderstorm days in Poland (1951-2000). Atmos. Res., 93: 506-515.

Bielec-Bąkowska Z., Matuszko D. 2006. Warunki meteorologiczne sprzyjające występowaniu groźnych burz w Małopolsce, [in:] Chełmicki W. (ed.) Meteorologiczne, hydrologiczne i geomorfologiczne zjawiska ekstremalne w południowej Polsce. Folia Geogr., ser. geogr.-phys., 35-36: 113-131.

Bodzak P. 2004. System detekcji i lokalizacji wyładowań atmosferycznych. Gazeta obserwatora IMGW, 5.

Brázdil R., Štěpánek P., Vais T. 1998. Časová a prostorová analýza bouŕek, krupobiti a extrémnich srážek v jižni části Moravy v obdobi 1946-1995. Meteorol. Zpr., 51, 2: 45-52.

Brooks H.E. 2013. Severe thunderstorms and climate change. Atmos. Res., 123: 129-138.

Changnon S.A. 1985. Secular variations in thunder-day frequencies in the Twentieth Century. J. Geophys. Res., 90: 6181-6194.

Changnon S.A. 1993. Relationships between thunderstorms and cloud-to-ground lightning in the United States. J. Appl. Meteorol., 32: 88-104.

Changnon S.A. 2001a. Damaging thunderstorm activity in the United States. Bull. Amer. Meteor. Soc., 82: 597-608.

Changnon S.A. 2001b. Assessment of the quality of thunderstorm data at first-order stations. J. Appl. Meteorol., 40: 783-794.

Changnon S.A., Changnon D. 2001. Long-term fluctuations in thunderstorm activity in the United States. Clim. Change, 50: 489-503.

Chromá K., Brázdil R., Tolasz R. 2005. Spatio-temporal variability of halistorms for Moravia and Silesia in the summer half-year of the period 1961-2000. Meteorol. Čas., 8: 65-74.

Dai A. 2001. Global precipitation and thunderstorm frequencies. Part I: Seasonal and interannual variations. J. Climate, 14: 1092-1111.

Dubicki A., Słota H., Zieliński J. (eds). 1999. Dorzecze Odry: monografia powodzi, lipiec 1997. Inst. Meteorol. i Gosp. Wod., Ser.: Atlasy i Monografie, Warszawa.

Enno S.E., Post P., Briede A., Stankunaite I. 2014. Long-term changes in the frequency of thunder days in the Baltic countries. Boreal Env. Res., 19: 452-466.

Grela J., Słota H., Zieliński J. (eds.). 1999. Dorzecze Wisły: monografia powodzi, lipiec 1997. Inst. Meteorol. i Gosp. Wod, Ser.: Atlasy i Monografie, Warszawa.

IPCC. 2013. Climate Change 2013: The Physical Science Basis. Contribution of Working Group I to the Fifth Assessment Report of the Intergovernmental Panel on Climate Change [Stocker, T.F., D. Qin, G.-K. Plattner, M. Tignor, S.K. Allen, J. Boschung, A. Nauels, Y. Xia, V. Bex and P.M. Midgley (eds.)]. Cambridge Univ. Press, Cambridge, United Kingdom and New York, NY, USA.

Janiszewski F. 1988. Instrukcja dla stacji meteorologicznych. Inst. Meteorol. i Gosp. Wod, Ser.: Instrukcje i podręczniki. Wyd. Geol., Warszawa.

Kolendowicz L. 2005. Wpływ cyrkulacji atmosferycznej oraz temperatury i wilgotności powietrza na występowanie dni z burzą na obszarze Polski. Wyd. Nauk. UAM, Poznań.

Kozłowska-Szczęsna T., Krawczyk B., Kuchcik M. 2004. Wpływ środowiska atmosferycznego na zdrowie $i$ samopoczucie człowieka. Pol. Akad. Nauk, Inst. Geogr. i Przestrz. Zagosp., Monografie, 4.

Kuleshov Y. 2012. 04 Thunderstorm and Lightning Climatology of Australia. Modern Climatology. Book 11. http://digitalcommons.usu.edu/modern_climatology/11

Kunz M., Sander J., Kottmeier Ch. 2009. Recent trends of thunderstorm and hailstorm frequency and their relation to atmospheric characteristics in southwest Germany. Int. J. Climatol., 29: 2283-2297.

Loginov V. F., Volchek A. A., Shpoka I. N. 2010. Estimation of the Role of Various Factors in the Thunderstorm Formation on the Territory of Belarus. Russ. Meteorol. Hydro., 35, 3:175-181. 
Olechnowicz-Bobrowska B. 1970. Częstość dni z opadem w Polsce. Pr. Geogr. IG PAN, 86: 375-385.

Reap R.M., Orville R.E. 1990. The relationships between network lightning locations and surface hourly observations of thunderstorms. Mon. Weather Rev., 118: 94-108.

Saha U., Maitra A., Midya S.K., Das G.K. 2014. Association of thunderstorm frequency with rainfall occurrences over an Indian urban metropolis. Atmos. Res., 138: 240-252.

Simeonov P., Bocheva L., Marinova T. 2009. Severe convective storms phenomena occurrence during the warm half of the year in Bulgaria (1961-2006). Atmos. Res., 93: 498-505.

Štěpánek P. 2010. An-Clim - software for time series analysis. Dep. of Geogr., Fac. of Nat. Sci., Masaryk Univ., Brno, 1.47 MB (http://www.climahom.eu/AnClim.html)

Twardosz R. 2010. A synoptic analysis of the diurnal cycle of thunderstorm precipitation in Kraków (Southern Poland). Int. J. Climatol., 30, 7: 1008-1013.
Ustrnul Z., Czekierda D. 2009. Atlas ekstremalnych zjawisk meteorologicznych oraz sytuacji synoptycznych w Polsce (Atlas of extreme meteorological phenomena and synoptic situations in Poland). Inst. Meteorol. i Gospod. Wod..

Wei J., Liu M., Zhang B., Yu J. 2011. Analysis of the trends of thunderstorms in 1951-2007 in Jiangsu province. J. Trop. Meteor., 17, 1: 58-63.

Wrona B. 2003. Synoptyczne uwarunkowania intensywnych opadów deszczu na Dolnym Śląsku w lipcu 2001 roku. Wiadomości IMGW, 26: 39-54.

Wrona B. 2008. Meteorologiczne i morfologiczne uwarunkowania ekstremalnych opadów atmosferycznych $w$ dorzeczu Górnej i środkowej Odry. Inst. Meteorol. i Gospod. Wod., Mat. Badawcze, seria: Meteorologia, 41, Warszawa.

Zheng L-L., Sun J-H., Wei J. 2010. Thunder Events in China: 1980-2008. Atmos. Oceanic Sci. Lett., 3, 4: 181-188. 